\title{
Origins and Development of the Field of Prehistory in Burma
}

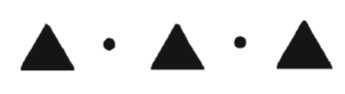

MICHAEL A. AUNG-THWIN

THE GOALS OF THIS PAPER are twofold: first, and primarily, to summarize the circumstances under which the study of prehistory evolved in Burma; and second, to identify the issues and problems in it, thereby suggesting possible research topics for future students of Burma's prehistory.

As a historian of early Burma, however, I tread with a great deal of caution over the many layered minefields of prehistory. Yet, at the same time, I do not carry the same theoretical baggage borne by those in the discipline of prehistory (by definition, itself a Western invention) and therefore may be able to see things in a different way. And one of those intellectual pieces of baggage that, for long, has been carried by prehistorians (as well as historians) is the assumption that differences imply change, change implies progress, and progress is demonstrated by differences - essentially a circular argument. Ultimately, the logic rests on a linear concept of time, which in turn is assumed to be a motor for progress, so that it is the idea of progress itself that generates conclusions of progress (Aung-Thwin 1991).

This is all the more troubling since one thing that stands out clearly in Burma's prehistory is the evidence for continuity. And, it is compelling: one simply cannot tell when, or identify where, a defined period (such as the Palaeolithic) ends and the next defined period (such as the Neolithic) begins, not to mention the metal periods that follow and continue right to today. Besides, these periods are Western categories created to organize, initially anyway, the discipline of prehistory - essentially only a heuristic device - and based largely on its own geologic, geographic, palaeontologic, and archaeologic evidence, which in turn has been contextualized by Western assumptions about human nature, progress, and time.

For these and other theoretical reasons-not least that I am a historian rather than a prehistorian-the following treatment of Burma's prehistory will be mainly a synthesis of the existing published literature on the subject, most of it in the English language, and the data contained therein. I have also used a few unpublished (mimeographed) and published sources in Burmese, along with some written in English but published in Burma and therefore difficult to obtain. These are reflected in my list of references. 
I have attempted to organize the work more or less thematically and chronologically, that is, the actual manner in which geology and archaeology developed in Burma from the late nineteenth century until today. Since I am not dealing with primary but only secondary evidence, it means I must rely on the soundness of the data, analyses, and conclusions made by the those who did. However, my hope is that my own knowledge of the early history of Burma may help in placing this prehistoric "period" in a more meaningful (at least, Burma) context.

I do use terms and phrases such as "Palaeolithic" or "Neolithic Age," for among other reasons, not only is there evidence of continuity in the style of stone implements that "transgressed" these periods, but also because stone continued to be used when iron and other metals were already known and used. Therefore the distinction between these artificially created epochs become a bit meaningless. (Now, admittedly, the notion of an "age," say of commerce, used by Southeast Asia historians, is just as problematic as the prehistorian's use of the term Neolithic Age.) However, there is no practical way to completely avoid using some of these terms, particularly when discussing the work of other scholars who did. The following, then, is an analytical synthesis of the published and unpublished literature on the study of Burma's prehistory with the above concerns in mind.

\section{THE PLEISTOCENE GEOLOGY OF UPPER BURMA}

Although there are numerous focused articles on the specific geology of Burma in academic periodicals, such as the now defunct Journal of the Burma Research Society ${ }^{1}$, as well as in some other publications in Burmese and English that have appeared in recent years, such as the Myanmar Naingnan Thuthethana Sasaung, we still rely on H. L. Chhibber's 1934 The Geology of Burma, the standard reference for the country's overall geology (Chhibber 1934). For our purposes here, however, certain select works by several Western geologists regarding the Pleistocene chronology of Upper Burma provide the geologic foundations for the prehistory of (at least Upper) Burma. Some of the most detailed accounts are old but still solid, having been written by scholars such as Fritz Noetling (1895), G. E. Grimes (1900), E. H. Pascoe (1912), G. Cotter (1918), D. L. Stamp (1922), E.L.C. Clegg (1938), P. Evans and C. A. Sanson (1941).

The initial incentive for studying the geology of Burma was not academic but economic: it had to do with the search for oil in the fields of Yenangyaung and Chauk in the Irrawaddy Valley in Upper Burma by the British colonial government (Map 1). As a result, knowledge regarding the Tertiary beds of that region had been well established rather early. But not until the work by T. O. Morris in the 1930s, who was then a geologist with Steel Bros. and Co. Ltd., was there probably any serious attempt to study the prehistory of Burma using this geologic knowledge.

Morris was followed by a team consisting of a professional prehistorian and a geologist, Hallam Movius and Helmut de Terra, whose conceptualizations of the Burma case was, at the time (and arguably today), the most cogent, and also the best documented. They focused on the Pleistocene terraces of the Irrawaddy Valley with prehistory in mind, so that virtually everyone concerned with the subject subsequently invariably ended up citing them (de Terra 1944; de Terra and Movius 1943; Movius 1948). Figure 1 and Table 1 clarify the chronological sequence. 


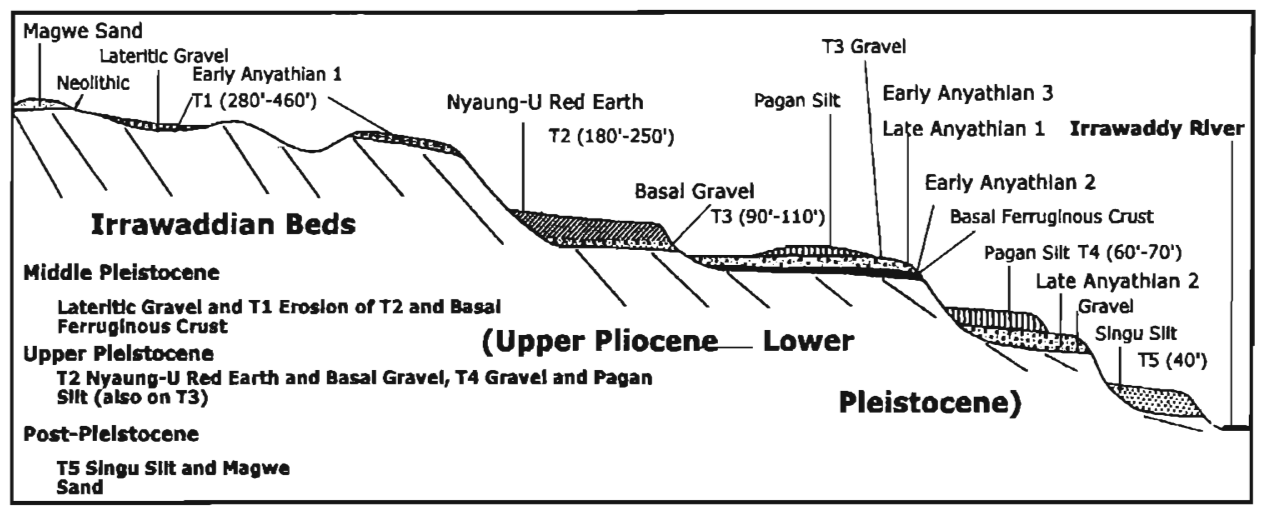

Fig. 1. Pleistocene terraces. (Adapted from Movius 1948.)

The Irrawaddy River continued to cut a wide valley after the middle Pleistocene (Fig. 2), later filled in part by deposits of Terrace 2 (T2) and Terrace 3 (T3). On the valley floor, a cemented ferruginous crust formed, which yielded Early Anyathian Phase 2 implements. This crust is exposed under Terrace 3 at various places along the river, about 90 to $110 \mathrm{ft}$ above the river. The rock debris as well as the implements found within the crust have a "typical" desert patina or varnish.

Terrace 2 was formed during a period when the rainfall of Upper Burma was two to three times that of current times, and has been associated with the Third Glacial Stage of the Himalayas. Upper Burma's T2 deposits consist of basal gravel with 50 to $60 \mathrm{ft}$ of what is called Nyaung-U Red Earth, found in wide blocks 180 to $250 \mathrm{ft}$ above the river. According to Movius, the T2 basal gravels, which are exposed on T3, are rich in archaeological materials that he thinks belong to Phase 3 of the Early Anyathian culture (to him, equivalent to the last phase of the Lower Palaeolithic of Europe).

Table I. Chronological Table of Geological Sequences and Sites

\begin{tabular}{|c|c|c|c|c|}
\hline & $\begin{array}{l}\text { GEOLOGICAL } \\
\text { EPOCH }\end{array}$ & $\begin{array}{l}\text { GEOLOGICAL } \\
\text { MATERIAL }\end{array}$ & MOVIUS SITE & $\begin{array}{c}\text { MOVIUS } \\
\text { CHRONOLOGY }\end{array}$ \\
\hline T1 (280-450) & Middle Pleistocene & Lateritic Gravel & Magwe & $\begin{array}{l}\text { Early Anyathian, } \\
\text { Phase } 1\end{array}$ \\
\hline T2 (180-250) & Upper Pleistocene & $\begin{array}{l}\text { Basal fluvial } \\
\text { gravels, red } \\
\text { earth, sand }\end{array}$ & $\begin{array}{l}\text { Magwe, Minbu, } \\
\text { Yenangyaung, } \\
\text { Chauk, Pagan, } \\
\text { Pakokku }\end{array}$ & $\begin{array}{c}\text { Early Anyathian, } \\
\text { Phase } 3\end{array}$ \\
\hline T3 $(90-110)$ & Upper Pleistocene & Basal gravels & Pagan, Nyaung-U & $\begin{array}{c}\text { Early Anyathian, } \\
\text { Phase } 3\end{array}$ \\
\hline T4 (60/70-90) & Upper Pleistocene & $\begin{array}{c}\text { Gravels, sands, } \\
\text { loessic silt }\end{array}$ & Magwe, Pauk & $\begin{array}{l}\text { Late Anyathian, } \\
\text { Phase } 2\end{array}$ \\
\hline T5 $(40 / 60-70)$ & $\begin{array}{l}\text { Post Pleistocene } \\
\text { (recent stage) }\end{array}$ & $\begin{array}{l}\text { Singu silt, } \\
\text { Magwe sand }\end{array}$ & Singu, Magwe & $\begin{array}{l}\text { Late Anyathian, } \\
\text { Phase } 2\end{array}$ \\
\hline Valley Floor & Current & $\begin{array}{l}\text { Cemented } \\
\text { ferruginous } \\
\text { crust }\end{array}$ & Nyaung-U & $\begin{array}{l}\text { Early Anyathian } \\
\text { Phase } 2\end{array}$ \\
\hline
\end{tabular}


To a geologist, the most conspicuous feature in the Irrawaddy Valley between Magwe on the south and Mandalay on the north - the main area under discussionis Terrace 3, a wide level 90 to $110 \mathrm{ft}$ above the Irrawaddy. It is thought to be the counterpart of the Third Interglacial in the Himalayan sequence. On top of T3 are also T2 fluvial gravels and sands, which contain the main implements of the Early Anyathian.

Terrace 4 was formed during the Fourth Pluvial Stage, belonging to the late Upper Pleistocene, found at a height about 60-70 ft above the river. Here, in the gravels and sands laid down at this time, Movius found slightly rolled implements, which he says are typical of the Late Anyathian culture, along with heavily rolled material from the Early Anyathian that sat higher on the horizon. Loessic silt, called Pagan Silt, lies on top of the T4 deposits, equivalent to the Potwar Silt of northwestern India, and typical of the pluvial loess one finds in the semi-arid areas south of the Himalayas.

Some $40 \mathrm{ft}$ above the Irrawaddy sits Terrace 5 (T5), a low silt level formed during what Movius called the "recent stage." It contains "Neolithic" and later archaeological material, and it is closely associated with the low silt terrace of the Punjab. It is at this time that the deposit called Magwe Sand was laid down on the peneplain.

The contribution of geological stratigraphy is of course indispensable to prehistory, especially if, in the absence of clear pre-sapiens hominid finds, the fauna, more than stratigraphy, may be able to place Burma assemblages within one or more of the Pleistocene levels, as has been done with $\mathrm{K}$ 'o-ho in China (Chang 1986, p. 48).

\section{BURMA'S EARLY STONE CULTURES}

I use the term "stone cultures" to avoid, as much as possible, Western categories and assumptions that lie underneath the categories found in terms such as the Palaeolithic and Neolithic. However, prehistorians of Southeast Asia do the same when they use the term "Hoabinhian" (taken from the village of Hoa Binh in Viet Nam) as a designation for a Southeast Asia-wide stone culture, arguably as centric as the term Bacsonian. We historians also do this unabashedly in categorizing the early history of Southeast Asia in phrases such as "Urban Age," "Classical Age," "Early Modern Age," "Age of Commerce," and now, the "Post-Modern Age."

But unlike prehistory, at least the historic periods have a relative abundance of literary and other evidence with dates, events, names, and institutions that can be linked to each other more clearly. We are not dependent on a piece of a skull (or two) that may be the only reliable evidence for making conclusions on an entire region covering a million years. And historians of early Southeast Asia do not have to guess to which "period" certain peoples, kingdoms, cities, or events belong (for they are more often than not dated by more than one primary source), whereas prehistory often has to explain (and assign) evidence belonging to overlapping sequences and chronologies of geology, palaeontology, and culture. Historians can also document changes taking place (of a permanent or temporary nature) with regard to kingdoms, cities, dynasties, or individuals. We know fairly well when they rose, when they expanded, and when they declined. We also do not have to guess whether or not whole populations were "replaced" based on a 
few changes in the style of (say) pots. Still, I must admit that prehistorians and archaeologists in general are often more rigorous in their demand for unequivocal evidence before arriving at conclusions than historians; perhaps precisely because of the stingy nature of the evidence.

It should come as no surprise, then, to state that the study of Burma's prehistory, according to the criteria desired by prehistorians, is very much in its infancy, if not still in the womb. Limited interest in the freld in the Western sense probably began with Dr. Fritz Noetling of the Geological Survey of India. In 1894 and 1897 (Noetling 1894, 1897), he published reports of an Upper Miocene or early Pliocene deposit in which were found what are now considered the first stone implements to be recorded from Burma. Subsequently, during the early 1900s, Noetling's find and conclusions triggered some interest in the subject among individuals such as R. D. Oldham (1895), R.J.C. Swinhoe (1903), and E. H. Pascoe (1912).

Controversy began almost immediately. It lay essentially on the stratigraphy from which the implements were discovered, which Noetling claimed were found in situ. Others that followed him found similar implements on the surface, sometimes $100 \mathrm{ft}$ above Noetling's stratum. In other words, although no one disagreed with Noetling's conclusion that these had human origins, they rejected the claim that these (or such) implements were necessarily associated with Noetling's stratum, called the "Red Bed," a reference to the Upper Miocene or Lower Pliocene strata.

On one side of the controversy were those led by Oldham, Pascoe, and the others mentioned above, who considered Noetling's thesis "improbable" (Pascoe $1912,1: 53-54)$. On the other side were prehistorians of India such as H. C. Das Gupta and Panchanan Mitra who supported Noetling's conclusions (Das Gupta 1923; Mitra 1927). They were convinced that Noetling's specimens had occurred in situ in the "Red Bed," that is, the basal laterite bed, though they had had no field acquaintance with the locality. Others like J. C. Brown eventually joined the debate, stating that much ink had been spilt over not enough data (Brown 1931). Finally, T. O. Morris, armed with some fresh data that many similar chipped implements were found far away from the "Red Bed" of Yenangyaung where Noetling found his, wrote five articles on the subject in the Journal of the Burma Research Society between 1932 and 1937, in which he concluded that although the implements of Noetling may have once belonged to the surface, they were redeposited in association with Pliocene beds (Morris 1932, 1935, 1936a, 1936b, 1937).

That particular conclusion was affirmed by Hallam L. Movius, Jr. who led the American Southeast Asiatic Expedition during the "digging season" of 1937-38. However, he disagreed with Morris' attribution of the implements to the Upper Palaeolithic period (de Terra and Movius 1943). Movius believed that the materials found by Noetling were not only associated with the post-Pleistocene Magwe Sand, but also with pottery and polished stone and is therefore Neolithic in age. In addition, Movius, along with Helmut de Terra and P. de Chardin Teilhard, was said to have personally examined the stone implements Morris had given to the British Museum and concluded "with certainty" that "hand-axes are absent in the Burmese Palaeolithic" (de Terra and Movius 1943:341).

However, Morris claimed he had found a large "hand axe" which he describes in the following manner. "The implement is a hand axe of Chelles type, fash- 

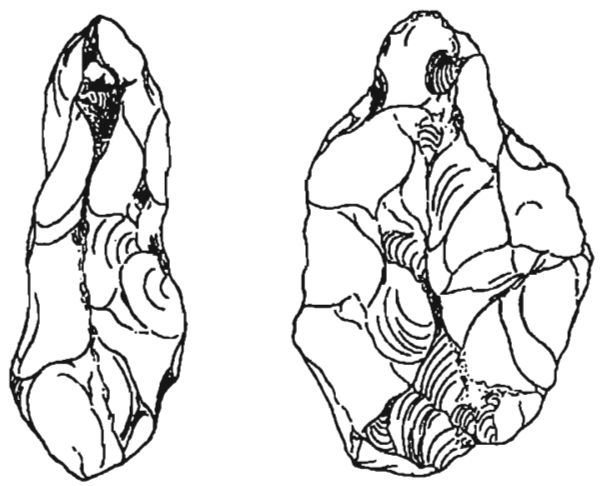

Fig. 2. Acheulean "hand

axe" from surface of $\mathrm{T} 3$.

(Adapted from Morris 1936a.)

ioned from a block of silicified monocotyledonous wood. Large flakes have been struck boldly and skilfully [sic] from one face, but from the other only three or four chips have been removed. There has been no attempt to improve its symmetry by flaking smaller chips from the edges. Numerous silicified bundles of vascular tissue which penetrate the fossil wood give the flakescars a rougher surface than is usual on European flint implements of similar type; otherwise the workmanship is identical ..." (Morris 1932:19).

Subsequently, about four years later, he found another, smaller sample. "The small hand axe ... was picked up recently on the Yenangyaung Golf Course by Mr. E. S. Pinfold. It is made of felsite, now patinated various shades of deep cream and brown, and is about three inches long. The implement belongs to the Chelleo-Acheulean series of cultures, but the particular stage to which it should be assigned is somewhat difficult to determine. It is [a] much later type than the early Chellean hand axe which I described in this Journal a few years ago ..., but although the whole of its surface is flaked the roughness of the flaking and the relative thickness of the implement weigh against its being classed as Acheulean. These features, however, may be due more to the poor quality of the material employed than to primitive workmanship. There are signs that its maker intended to carry out finer flaking around the edges, but was deterred from doing so by the irregular grain of the rock. Further, the edges possess a signoidal twist characteristic of the later stages of Acheulean culture. On the whole I am inclined to think the balance of evidence is in favour of an Acheulean date for the implement, rather than late Chellean" (Morris 1936a:119; Fig. 2).

Morris had further qualified his statements by saying that "the form and materials of the chipped implements are quite distinct from those of the neoliths. To this distinction may be added that of distribution - the palaeoliths seem to be restricted to the higher terraces, whereas neoliths occur on all levels down to and including the Konbyin (T4), and probably within the Lebyin (T5) alluvium" (Morris 1935:8). And he also clearly admitted that "until further investigations have established a stratigraphical succession of chipped implement types for Burma any attempt to arrange surface finds in a time sequence on the evidence of their own forms must depend on the succession of cultures already worked out in Europe and around the Mediterrean. Considered from this point of view it seems to me that representatives of three cultural stages, widely separated in time, can be 
recognised in collections made up to the present-Eolithic, Chellean, and Upper Palaeolithic."

Morris' work is important for other reasons. His 1935 article is the only one I know of that explicitly lists the people who donated Burma-found implements to various museums, where I presume they still exist, and is therefore an important archive for future researchers. Theobald and G. Fryer donated about 60 specimens to the Indian Museum, Calcutta, illustrated and described by Theobald and Brown (Brown 1917; Theobald 1873). Some 20 specimens collected by J. C. Mackenzie, now apparently lost, were fortunately mentioned by Brown in another publication (Brown 1931:33-43).

In the British Museum are more materials. A shouldered adze from Prome was presented by a Capt. A. G. Duff in 1865 (Smith 1926). Swinhoe donated five small axes in 1903, one from Popa and four from the Kachin Hills. R. Grant Brown in 1907 gave two small shouldered axes from Bokpyin, Mergui district. A Mr. W. A. Robertson donated two shouldered adzes from the southern Shan States and a large implement, which Morris thinks may be a ploughshare, from Toungoo, in 1919. Nineteen axes and adzes from the Kachin Hills and the Shan States were donated to the Museum by a Mr. N. G. Cholmeley in 1926. Ten axes and one adze from the Liepok Chaung (stream) Mergui district, were given in 1928 by a Mr. A. Braybon. To those, Morris himself added 60 representative specimens from various parts of the dry zone: the $\mathrm{Mu}$, Chindwin, and Irrawaddy valleys (Morris 1935:8). Today, the National Museum in Yangon has an entire wing of a floor displaying prehistoric implements. To what extent some of these in the National Museum are those earlier deposited in the Indian and British museums that may have been returned is difficult to say.

Morris also noticed that the Burma neoliths were obviously the cutting tools of a wood-working people-axes, adzes, wedges, and chisel blades, a conclusion verified 40 years later by William Solheim. Morris noted that "the small size and narrow blades of some adzes ... give some idea of the fine woodwork of which their Neolithic users must have been capable." They were "probably socketed in the end of straight handles and used precisely as modern wood chisels" (Morris 1935:9-11). The strong implements with blunt butts and wide-angled symmetrical cutting edges, he conjectures, were probably used as wedges in conjunction with wooden mallets for splitting timber evenly along the grain.

Morris also found ringstones, too small to be adult bracelets, but that he thinks were mounted on a lathe creating the linear notches on tools found at the intersection of shoulders and tangs of shouldered adzes. The ringstones are all ground to a sharp edge along their external circumference and have central holes of uniform diameter. Another found in Lower Chindwin district "has a central hole which diminishes from one side of the disc to the other and has a spiral groove cut in it apparently to make it grip a wooden axle more effectively" (Morris $1935: 12)$.

Of the 300 or so axes, adzes, wedges, and chisels studied by T. O. Morris, about 70 percent were made of siltstone, 10 percent schist, 10 percent dolerite, 4 percent porphyry, and 6 percent sandstone. Very few were made of felsite. Although siltstone comprises 70 percent of the implements studied, the material is not found in the central lowland region of Burma, yet the tools are found throughout "the length and breadth of the country," so that Morris felt there was 
an extensive trade in these stones with the hill regions on either side of the central valley. The siltstones are dark green in color.

As one can observe, by the time Movius came to the country on his expedition, Morris had done much of the background work. And to a certain, small degree perhaps, even Movius was swayed by Morris' use of Burmese terms, for he himself coined an indigenous term still with us today. Because, he argued, the implements collected during the American expedition were "fundamentally" different from those of Western Europe, the stone culture in Burma was given a new Burmese name: the Anyathian culture, after Anyatha, "Upper Burma Man."

\section{The Early Anyathian}

By Anyathian, it is clear from his numerous works that Movius meant all stages of the Western Palaeolithic. Thus, he asserts that in terms of a chronological sequence, the Early Anyathian roughly covers the time-span of the Lower and Middle Palaeolithic periods of the Old World while the Late Anyathian may be equivalent to the Upper Palaeolithic period. Furthermore, since the typology of the Anyathian is remarkably uniform throughout its entire sequence in Burma, he concluded that there was no stage of development in the Irrawaddy Valley corresponding to the Middle Palaeolithic of other regions (Movius 1948:366).

Movius' expedition made full use of de Terra and Teilhard's study of the stratigraphy, listing five terraces from the Lower to the post-Pleistocene, within which he placed Anyathian culture. He dispensed with Morris' Burmese terms for these terraces and used standard geological ones. His expedition then suggested that there were three phases belonging to the Early Anyathian culture and two phases to the Late Anyathian. The Early Anyathian was subdivided into three stages: the first stage chronologically placed in the Pluvial and Middle Pleistocene, the second in the Interpluvial, still in the Middle Pleistocene, and the third between the Middle and Upper Pleistocene during the second Pluvial.

The Early Anyathian 1 site is "heavily rolled and is found in situ in the lateritic gravel at Magwe" (see Map 1), as well as in the remnants of Terrace 1 (towards the end of the Lower Pleistocene) of the same deposit at Chauk and also at nearby Sale (de Terra and Movius 1943:346). Only 23 implements were collected at these sites but are important because they are considered to be the oldest human artifacts from the Irrawaddy Valley (Movius 1948:366; Fig. 3). They date from the pluvial period at the beginning of the Middle Pleistocene in Burma, when an extensive valley fill occurred that preserved the remnants of lateritic gravel on both T1 and the higher slopes of the Pegu Yoma (mountains).

Nearly 100 implements were found from the Early Anyathian 2 level, either in or associated with the basal ferruginous crust exposed under Terrace 2 at Nyaung$U$ (Fig. 4). Movius concludes: "Many of these display a typical desert varnish indicating actual occupation contemporary with the formation of the crust, which occurred during a long interpluvial period in the late Middle Pleistocene times. Others are rolled and may either be the same age as the gravels, which were later cemented to form the crust, or derived from older deposits" (Movius 1948:346).

Four hundred implements were found for Early Anyathian 3-which Movius considers to be the main development of the Anyathian-made from the gravel of Terrace 2 and exposed on Terrace 3 (Map 1) at Magwe, Minbu, Yenangyaung, 


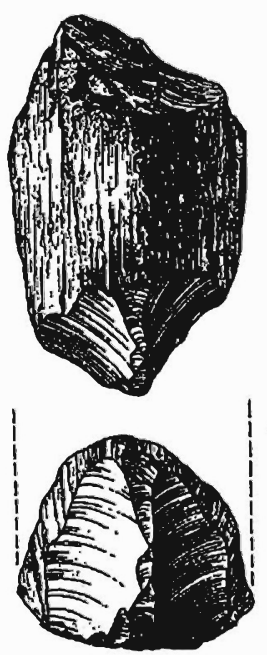

1
0

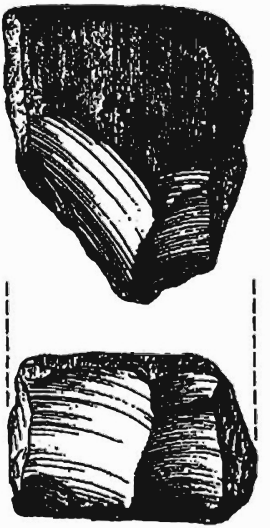

2

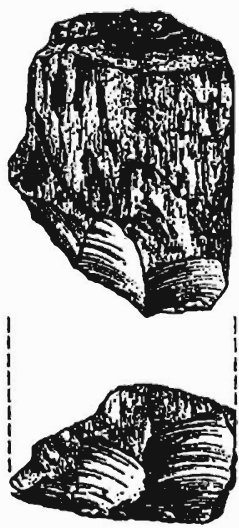

3

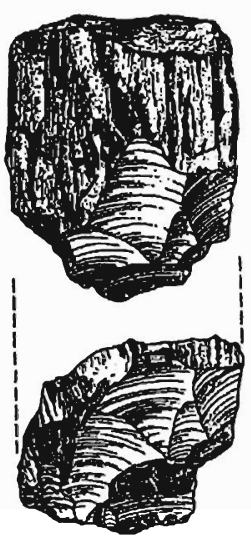

5
Fig. 3. Early Anyathian 1 implements. 1-3, 5: steepended hand adzes; 4: chopping tool with flaked edge made on pebble. (Adapted from de Terra and Movius 1943.)

4

Chauk, Pagan, and Pakokku (Fig. 5). All the implements are heavily rolled and "are probably contemporary with the deposition of the gravels-early Upper Pleistocene." But, he warns that in this deposit the "degree of rolling is an extremely dangerous criterion of age, as the gravels in question were subjected to considerable reworking during the succeeding period when T3 was cut" (Movius 1948: 346).

\section{The Late Anyathian}

The Late Anyathian is also divided into 1 and 2 subperiods, since the implements here seem to have more in common with each other than with the Early Anyathian. The sites are again the same or close to those of the Early Anyathian, namely, Magwe, Yenangyaung, and Chauk. He feels that the Late Anyathian 1 dates from the erosion period when $\mathrm{T} 3$ was cut, exposing the basal gravel deposits laid down during the preceding interval. Late Anyathian 1 implements displayed a 


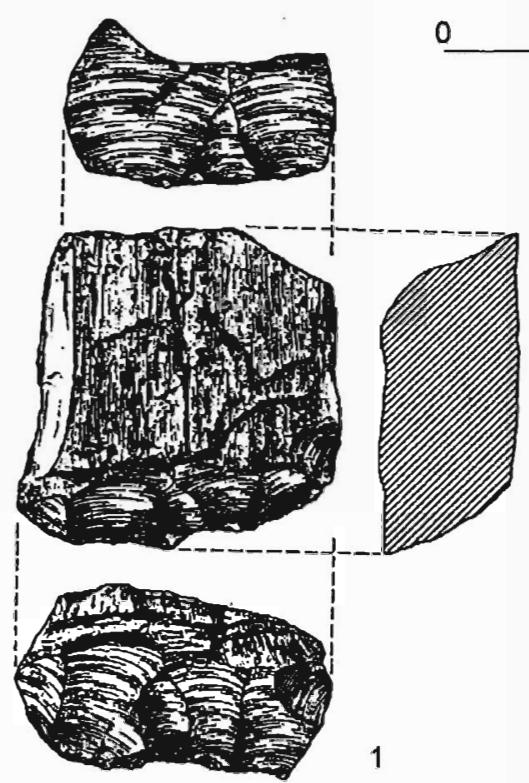

$5 \quad 10 \mathrm{~cm}$

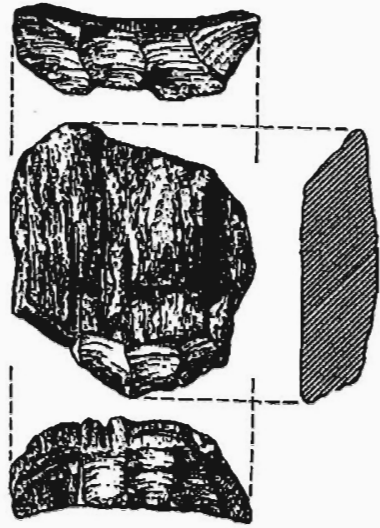

2

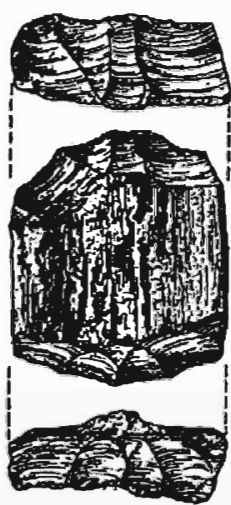

3

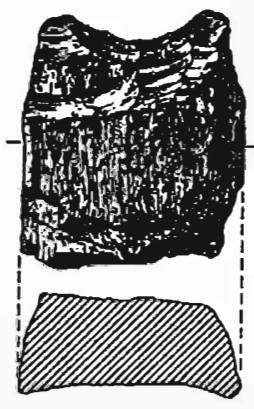

4

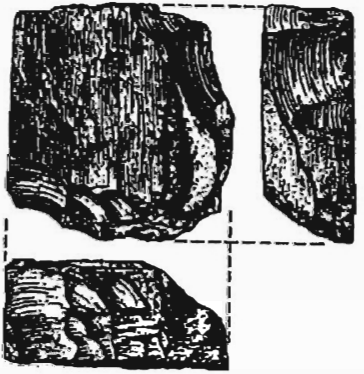

5

Fig. 4. Early Anyathian 2-3 implements of fossil wood. 1-2: inverse doubleended hand adzes; 3 : hand adze; 4: concave-ended hand adze; 5: singleended and side hand adze. (Adapted from de Terra and Movius 1943.)

more advanced flaking technique in addition to being smaller than the Early Anyathian 3 material (Fig. 6).

Then there is the Late Anyathian 2, the final development, according to Movius, of the Burmese Palaeolithic (Fig. 7). It occurs slightly rolled in the gravels of T4. Again, its implements were collected at Magwe, but also at Pauk, and in several places between Singu and Pagan. It seemed likely to Movius that the Late Anyathian phase 2 is associated with the Pagan Silt geological terrace, so that the current "Pagan dust" has been around for some time. ${ }^{2}$ Movius warns us that implements indistinguishable from those of the Anyathian appear as well in the Neolithic of Upper Burma. 

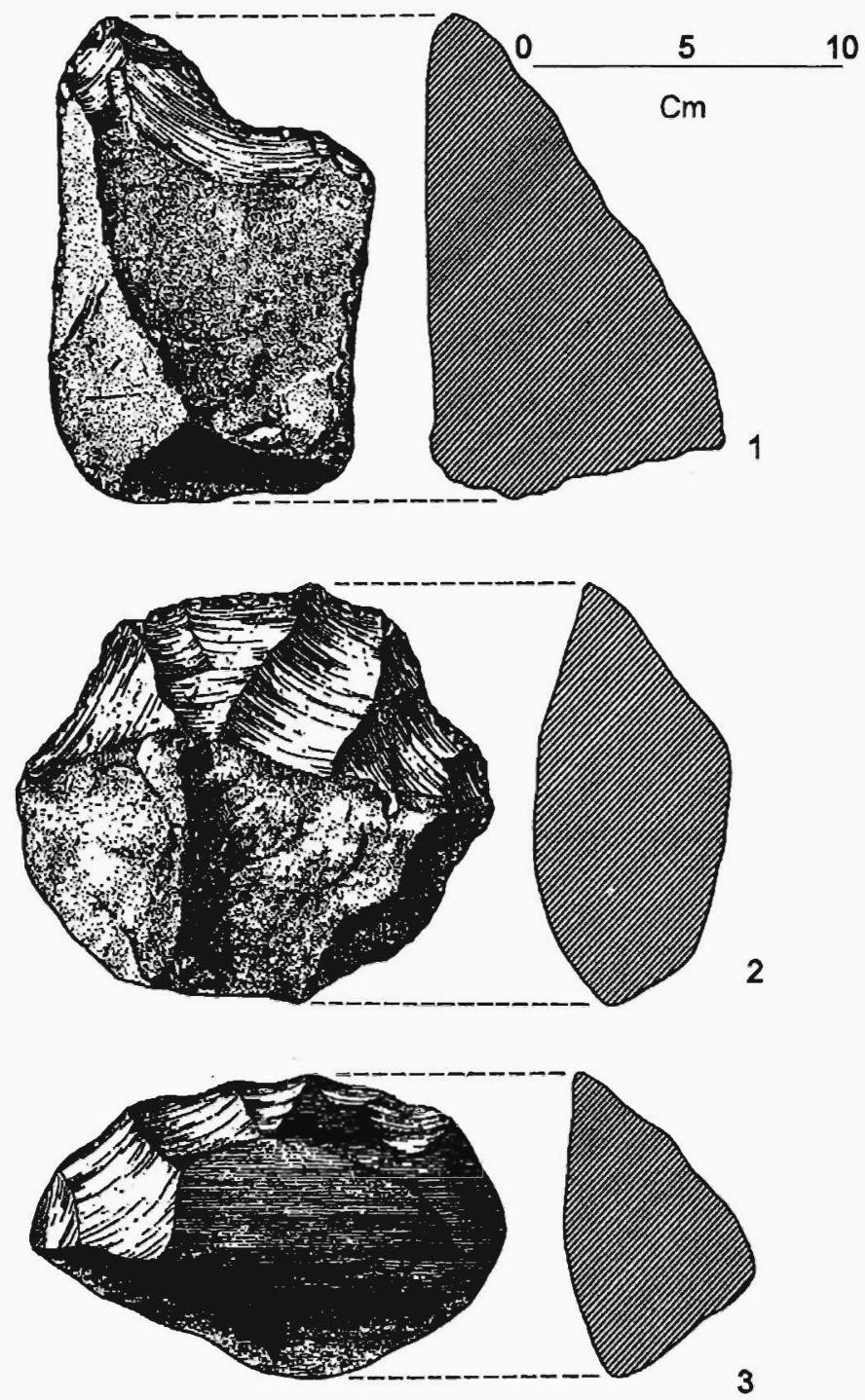

Fig. 5. Early Anyathian 3 choppers. 1-2: silicified tuff; 3: quartzite. (Adapted from de Terra and Movius 1943.)

The expedition Movius led recovered about 650 Anyathian implements, relatively speaking a small number, partly due to the enormous extent of the terraces. These implements were collected at twelve sites (Map 1) between Magwe and Nyaung-U, a distance of approximately 70 miles. For the most part, the tools are heavily rolled, and appear on the terrace surfaces where the gravels have been exposed. A "fair proportion was also extracted from sections cut through the terrace deposits, but no actual digging was done" (Movius 1948:347). He then goes into a detailed description of each site, the number of, and the circumstances in which the implements were found.

On the basis of the typology of tools made by the Early Anyathian people, Movius labeled it a chopper, chopping tool, hand-adze culture. Hand axes and true bifacial artifacts were not found during Movius' expedition (although he calls 


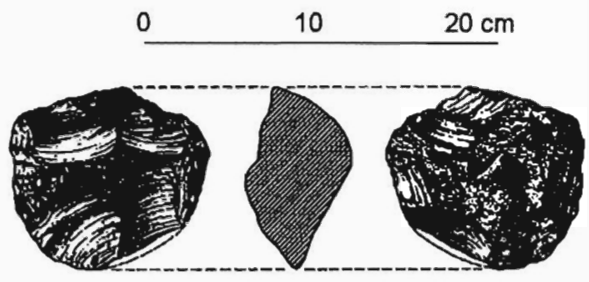

1
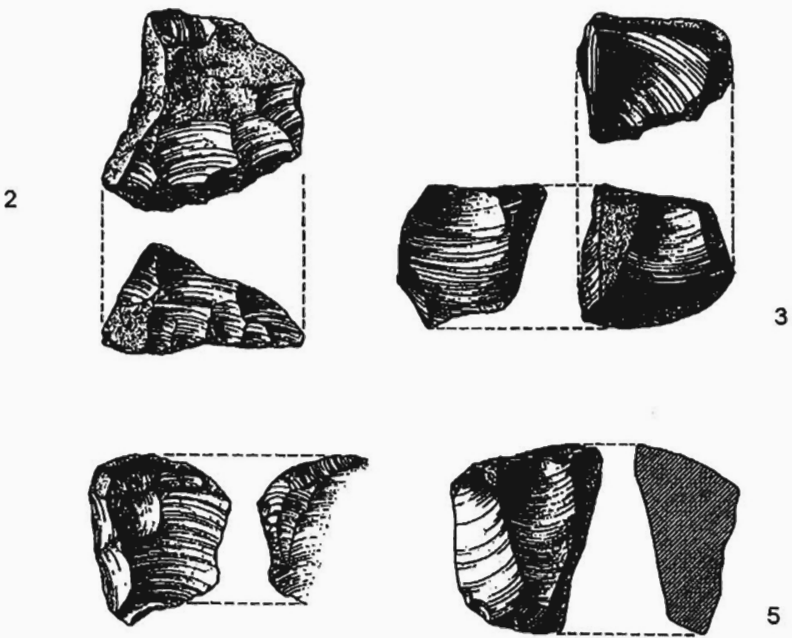

Fig. 6. Late Anyathian 1 implements of silicified tuff. 1: small bifacial chopper; 2: hand adze or flake chopper; 3, 5: cores or nuclei; 4: small flake implement. (Adapted from de Terra and Movius 1943.)

4

one a "proto-hand-axe"), which cannot be explained by the scarcity of good raw material. Rather, hand adzes and other choppers must have better fulfilled the functions which hand axes could (or did) not. (Indeed, hand adzes account for nearly 84 percent of all tools made of fossil wood found in the three main sites of Yenangyaung, Chauk, and Nyaung-U.) At any rate, the collection of tools from Burma "is far too limited to reveal any very marked developmental sequence ..." (Movius 1948:370).

Although there are some few simple flakes and nuclei, most of the choppers and chopping tools are "very similar in many respects to the Early Soan of the Punjab, and the large choppers associated with Sinanthropus at Choukoutien" (Movius 1948:348). Indeed, K. C. Chang (1986) places chopper-chopping tools in the Lower Palaeolithic level of development, contrasting them (and their erectus makers?) with the assemblage at T'ien-shui-kou in Tali county-only fifteen days walk during the early historic period from the current Burma-China borderwhere sapiens dwelled and chopper-chopping tools "are so rare to be insignificant" (Chang 1986, p. 56).

The Anyathian tool culture in Burma is also thought to be related to that found at Patjitan in Java, which is thought to be middle Pleistocene (de Terra and Movius 1943, p. 376). The implements found at Kota Tampan, near Lengong in the valley of the Perak River in Malaysia - although the dating here is unclear- 


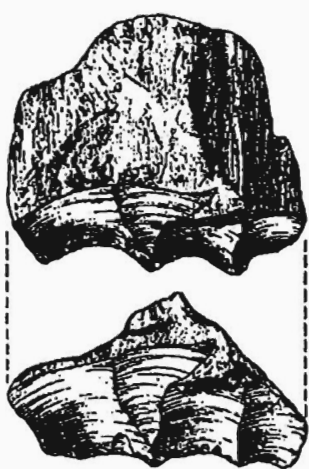

1

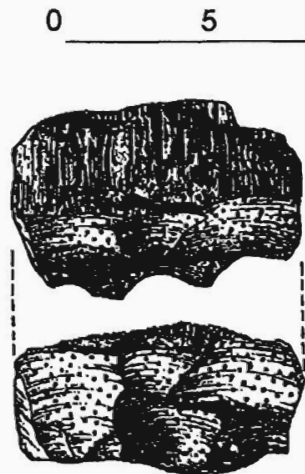

2
$10 \mathrm{~cm}$

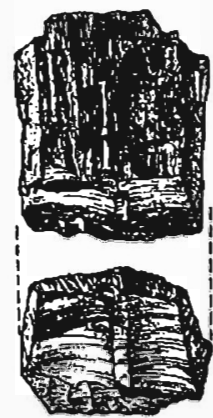

3

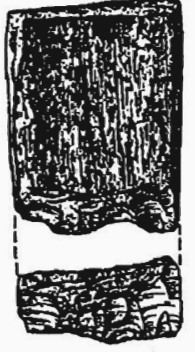

4

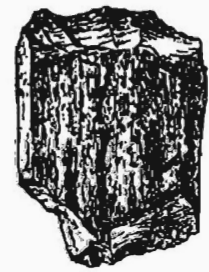

7

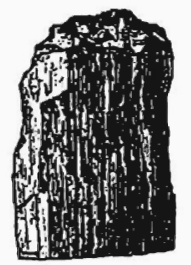

5

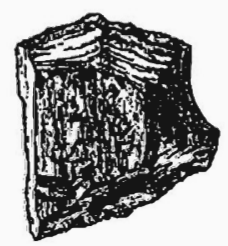

8

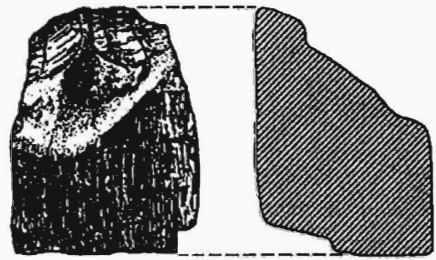

6

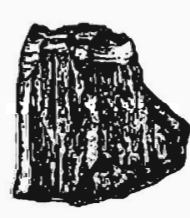

9

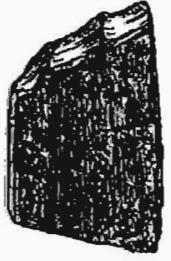

10

Fig. 7. Late Anyathian 2 implements of fossil wood. 1-2: hand adzes with scalloped edge; 3, 6: small steeped-ended hand adzes; 4-5, 9-10: end scrapers or small hand adzes; 7-8: double-ended scrapers. (Adapted from de Terra and Movius 1943.)

also seem very similar to the chopping tools of Burma, Java, China, and northwestern India.

Movius concludes that "the classic Western European sequence is absent in southeastern Asia, and that already during Lower Palaeolithic times we have to deal with independent complexes of cultures, which seem to have followed very different patterns of growth" (Movius 1948:378). Thus, there appears to be no stage of development corresponding to the Middle Palaeolithic of other regions, since "the typology of the Anyathian is remarkably uniform throughout the entire Old Stone Age sequence of Burma" (Movius 1948:341). ${ }^{3}$ The marked typologi- 
cal difference is between the Early and Late, and the various phases of each shows a "surprising degree of uniformity."

There are about 14 sites where Anyathian culture was found, spread over central Burma, most well known of which are Taungthaman in Amarapura, Taungbyon in Mandalay, Letpan Chay Baw in Nyaung-U/Pagan, and Hsa Hton in Salingyi. All of them are located in the dry zone (Map 2). The American team investigated about 12 sites, all in the Dry Zone. They lay along the west bank of the Irrawaddy stretching for about 70 miles, between Magwe on the south and Nyaung$\mathrm{U}$ on the north, adjacent to the ancient capital city of Pagan-subsequently the historic heartland of Burma. In addition to those, "Neolithic" sites "were found everywhere; the most important ones being at Magwe, Minbu, Yenangyaung, Singu, Nyaungu [Nyaung-U] and Kyaukpadaung in the Mt. Popa reigon" (Movius 1948:342).

\section{Raw Materials of Anyathian Implements}

The raw materials most extensively used by Anyathian man were silicified tuff and fossil wood. The former has a fine, homogeneous texture, almost identical to the best flint used during the European Palaeolithic. As for fossil wood, there was an almost inexhaustible supply during those times, deposits stretching hundreds of miles from the dry zone. As fresh water desert conditions are favorable to the formation of fossil wood, geologists, like Chhibber, have concluded that the climate of Upper Burma had for a long time been a dry one. Much of the fossil wood found here represents a characteristic tree of the Dry Zone, the toddy palm. A few implements were made from vein quartz and fine-grained quartzite.

Since silicified tuff is an excellent medium for tools and abundant in Burma, Anyathian man could make a limitless assortment of tools. Fossil wood, however, flakes in only one direction, so that all the implements made of this material tend to be of the same type. Thus, one cannot gauge "change" or "continuity" from one period to the next when analyzing implements made from fossil wood, for the nature of the fossil wood itself controlled the typology. As a result, Movius concluded that the "Upper Palaeolithic" of Burma is essentially similar to the "Lower Palaeolithic" when fossil wood implements are considered.

\section{The Post-Anyathian}

What I call the "post-Anyathian" should correspond to the Southeast Asian late "Hoabinhian" (and the Western "Neolithic"), although by no means is this not problematic, for, wrote Movius, "in the extreme north of the country there are people still using stone tools" (Movius 1948:385). The typical "post-Anyathian" sites found during the American expedition mentioned above are mostly from the region immediately east of the Kyaukpadaung-Popaywa road, where an abundant supply of fine-grained, white or pink silicified tuff, with flintlike appearances and smooth conchoidal fracture exist. This material in its raw state does not occur in the "Palaeolithic" sites discussed above, although artifacts made from it do, especially at Magwe. Here, implements and charcoal were found at the base of what has been called Magwe Sand, a loose red sand attaining sometimes thicknesses of 4-5 ft, thought to be of eolian origin. In addition to Magwe, "post-Anyathian" 
0 $5 \quad 10 \mathrm{~cm}$
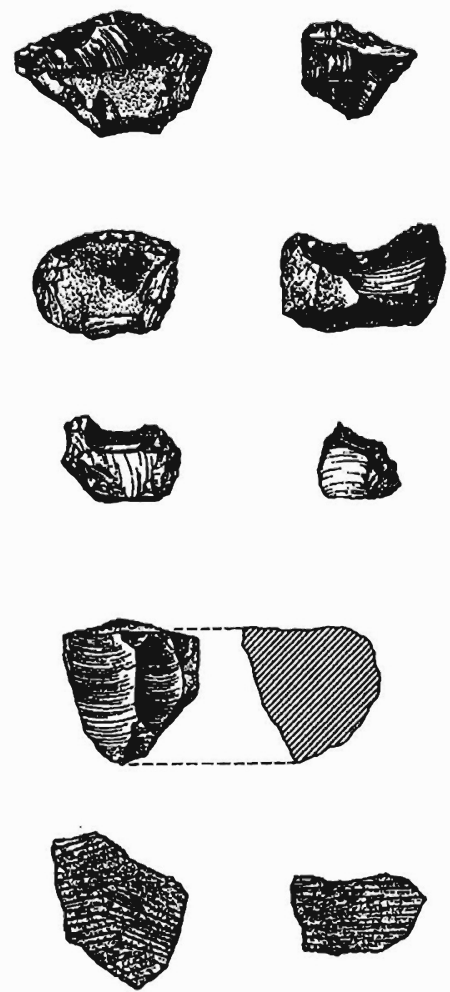
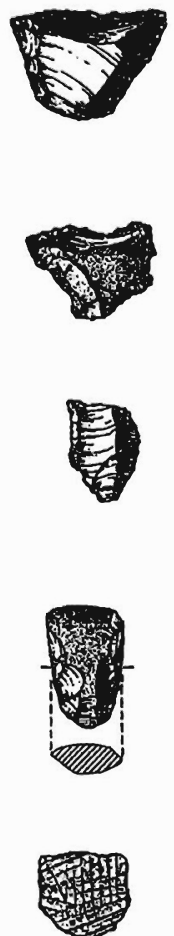

Fig. 8. Post-Anyathian ("Neolithic") implements from the vicinity of Kyaukpadaung. (Adapted from de Terra and Movius 1943.)

material was found at Minbu, Yenangyaung, Chauk, Pagan, and Nyaung-U. Materials were also found at Kyaukpadaung, at the base of Mt. Popa, near the village of Sebauk in the valley of the Sai Chaung, a tributary of the Taungzin Chaung (Fig. 8).

Most of the "post-Anyathian" implements are made of silicified tuff although other rocks were used and artifacts of fossil wood were found as well. They consist of scrapers, points, flakes, and small blades. In the case of the latter, many are identical with Late Anyathian forms, so that the distinction between Anyathian and the post-Anyathian in Burma is not all that clear (Fig. 9). Indeed, the "postAnyathian" sites are situated between Magwe and Nyaung-U along the Irrawaddy River, where the Anyathian sites are also located (Maps 1, 2).

Potsherds were also found in situ at Kyaukpadaung in the alluvium that covers the floor of the valley and therefore presumed to be the same age as the stone tools. They are of coarse texture, with numerous grits, and a light brown or reddish color, matt- or cordmarked. Magwe also contained the same type of implements found at Kyaukpadaung, in direct association with Magwe Sand. The cultural layer is at the base of the sand that overlays the Nyaung-U red earth of the middle Pleistocene. Polished stone implements, stone axes or celts, were also uncovered, along with the potsherds. The ware is a dark brick-red color. It is well fired and of finer texture than the pottery at Kyaukpadaung, better finished, 
0

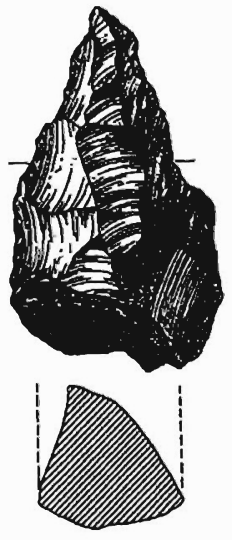

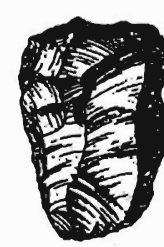

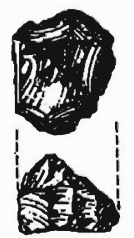

Fig. 9. Post-Anyathian ("Neolithic") implements from the vicinity of Kyaukpadaung. (Adapted from de Terra and Movius 1943.)

and has a more "sophisticated decoration" than the cordmarked ware (Movius 1948:382). Associated with these artifacts was a polished stone spindle whorl, $4.3 \mathrm{~cm}$ in diameter, and made of a fine-grained metamorphic rock. Type implements are also found at Pagan and Minbu. At the latter, a polished stone axe was found made of schist and a ringstone.

In short, the distinction between the Anyathian and the "post-Anyathian" in Burma, according to Movius' data, is that the former typically used large tools generally made on cores while the latter used blade and flake techniques. He felt that, therefore, "a new culture replaced the Anyathian" (Movius 1948:386). And for the first time, the outcrops of fine-grained silicified tuff in the Mt. Popa region were exploited and other materials such as vein quartz were used as well. However, it is possible that the same people simply discovered better tool designs for the silicified tuff and vein quartz, materials that they had been familiar with for a long time. Indeed, fossil wood tools similar to the Anyathian continue to be made and used.

Although the post-Anyathian record in Burma is sparse, it is not insignificant. This supposed equivalent to the Late Hoabinhian culture - if by that is meant the period in which agriculture and some animals were domesticated, where pottery is found, but where metal is not yet present-is neither easy to decipher nor differentiate precisely from whatever preceded and succeeded it.

Post-Anyathian sites, other than the Padah-lin caves described by Aung Thaw 

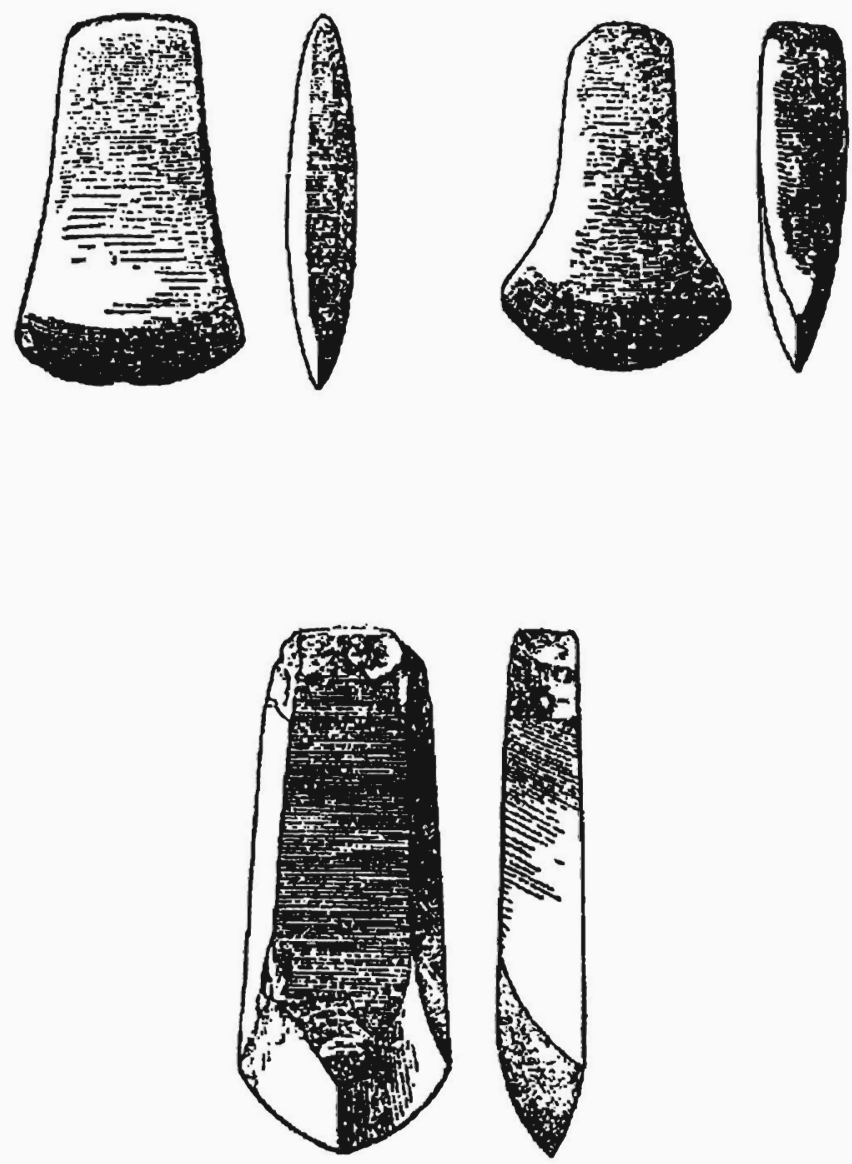

Fig. 10. Post-Anyathian ("Neolithic") axes and adzes. (Adapted from Morris 1935.)

in an earlier publication of Asian Perspectives, include Taungle in Prome district, Patalon Stream in Monywa district, the Kachin Hills, Liepok Stream in Mergui district, and Yeyein, in Shwebo district. All are in the Dry Zone. From them, an axe of green siltstone has been found, along with a shouldered adze of gray siltstone, an axe made of porphyry, another pointed adze of chalcedony, and a ringstone of dolerite (Fig. 10).

Movius seems to have fallen out of favor more recently among some prehistorians of Asia, in part perhaps because of his inclination to suggest a marked difference between the Zhou kovdian type cultures of China and Indo-China with those of the African and European Abbevillian and Acheulean industries, whereby he considered the former generally more primitive, and thus seemingly implying some sort of European superiority. His map (not shown here) reflected these two areas well, between what is now generally China cum Southeast Asia and India, which may have been influenced by the work of linguists who made a similar division between the Sinitic and Indo-European languages.

But that presumed Eurocentrism of Movius (even if true), and other problems, should not blind us to the contributions he made with regard to the solid data he gathered and presented-a very thorough job despite the little time he had in 
Burma-which is the best we have today on the Pleistocene prehistory of Burma in any case. Chang tempered the problem well when he wrote with regard to Movius' conclusions, that "there is little question that the East Asian Lower Palaeolithic cultures have their distinctive features, but one now wonders if their differences from contemporary cultures to the west were not exaggerated" (Chang 1986:47).

\section{WORLD WAR II AND ITS AFTERMATH ON BURMA'S PREHISTORY}

This relatively solid start in Burma's prehistory was interrupted by World War II. Once the war was over, conditions were far worse for the field of prehistory, as a struggle for power ensued between those who were in power and those who had been in power, relegating politics to the forefront. Thus, hardly had Burma become an independent nation in 1948 when civil war erupted, which continued for nearly another fifty years. In other words, for the past fifty years state and security concerns were the highest priorities, so that the last item to be earmarked for financial support from Burma's scarce resources was the study of prehistory. ${ }^{4}$

Another problem for prehistory, although not political in nature, was that increasingly during the 1970s and 1980s, the archaeological department focused its attention on the above-ground remains that belonged to the historic period, particularly of Pagan and the immediate pre-Pagan periods. Not only was the former spectacular in ways incomparable to other sites in Asia, the preservation work was less arduous, less time consuming, less expensive, certainly more cost-effective, and with a far better informational base with which to work: epigraphic, art historical, and historical.

Besides Pagan, excavations had been carried out during the first and second quarters of the twentieth centuries at several focused historical sites that had laid the foundations for Pagan (Map 2). It was done by the colonial Archaeological Survey of India by administrators untrained in archaeology although well versed in linguistics and philology. Subsequently, in the 1960s and 1970s, excavations of these historical sites were conducted by properly trained archaeologists, but they could be counted on one hand.

Spearheading all of it was the indefatigable Aung Thaw, trained in oldfashioned stratigraphy, along with his colleagues who made a significant difference. His excavation report on Beikthano Myo (Vishnu City) particularly, is the only scientifically and systematically excavated work that had (and has) been done in Burma of any major urban site. And it, along with another major site, Halin, that was only cursorily examined, nevertheless produced radiocarbon dates that for the first time allowed scholars to establish a reasonably reliable chronology of the millennium well before the rise of Pagan in the mid-ninth century A.D. (Even more interesting radiocarbon dates have been recently obtained by Bob Hudson, Mike Barbetti, and Peter Grave, whose contributions also appear in this volume.)

This urban period belonged to a people whose ethnonym (according to the Chinese) was Tircul, commonly known as the Pyu, thought to have been derived, ultimately, from the Chinese term for (presumably) them, namely, P'iao. We now know that there are nearly a dozen walled cities that belonged to this culture (and to these Tibeto-speaking people), almost all located in Upper Burma, most of them in the dry zone. But only Beikthano Myo, radiocarbon dated to the 

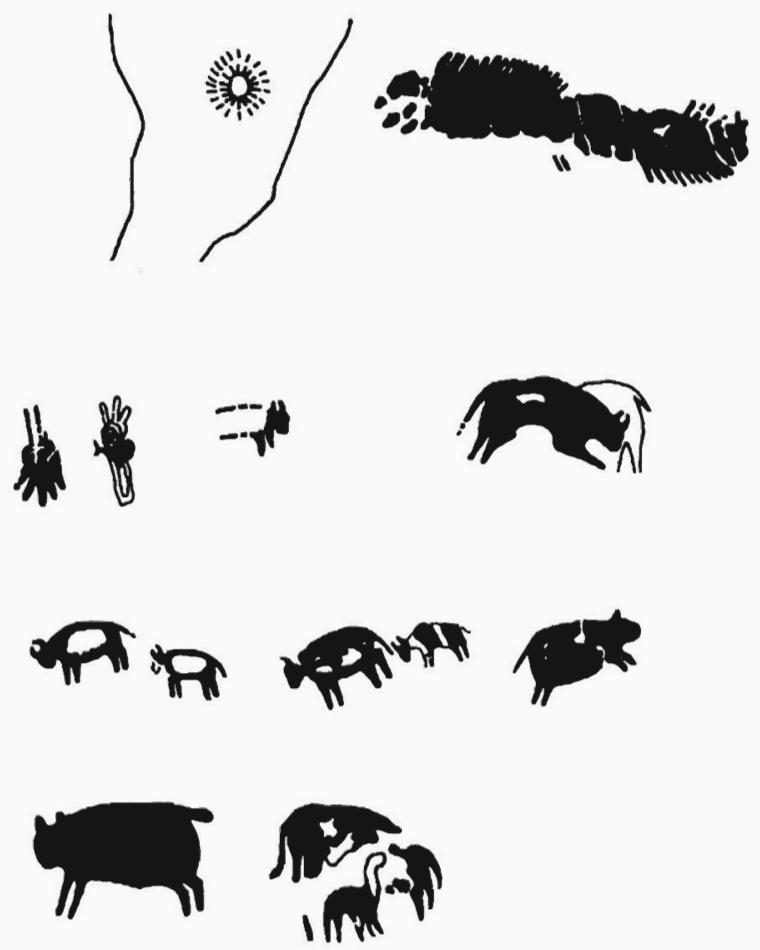

Fig. 11. Cave paintings at Padah-lin. (Adapted from Aung Thaw 1971.)

second century B.C., Halin also radiocarbon dated to between the second and ninth centuries A.D., and Sri Ksetra, epigrahically and art historically dated between the seventh and mid-ninth centuries A.D., have been examined properly (Aung Thaw 1972). Much more needs to be done even on these sites, not to mention the other cities that are still waiting the hands (and technology) of the scientifically trained archaeologist.

In short, the study of prehistory, already slow, with a low financial priority, was compromised even further by the desire to focus on historic sites, while higher, state demands on the scant human and material resources that were available in Burma were, understandably, placed elsewhere. Prehistory was a luxury that the country could ill afford, while the very few cases where foreign monies had been allocated for such study did not materialize for a variety of political, social, and infrastructural reasons.

\section{Burma's Post-Anyathian Cave Culture}

In 1960, a geologist, Khin Maung Kyaw, discovered what appeared to be prehistoric paintings in a group of caves in the Shan States, just west of the Shan plateau, generally composed of limestone, ranging from calcite to true dolomite (Fig. 11). By January of 1969, an expedition team of research workers was drawn from numerous scientific departments of Rangoon University (anthropology, geology, zoology). Led by the archaeological department, the investigation of what became known as the Padah-lin caves complex began (Aung Thaw 1971). The 
excavated portions reveal both Anyathian and post-Anyathian tool types at the same levels (altogether 1,600 artifacts), most of them representing the former. Of these, 422 were chosen to be examined in greater detail at headquarters. Many others were left buried near the camp. The tools are largely made of natural pebbles, without marks of secondary flaking or retouching, and resemble Anyathian tools. Hammerstones, mullers, unifacial choppers, bifacial choppers, hand adzes, and scrapers were represented. Flakes struck from pebbles or cores with prepared striking platforms were also found. Four specimens of bifacially flaked cores of medium size with double ends, pointed and rounded, were also uncovered. There is also evidence of grinding, found on an edge-ground flake scraper and flake adze, along with two small core tools that were almost completely ground, one of which has a sharp cutting edge. A small flake scraper with a beveled edge was among the finds. Patches of ground surfaces or ground edges can also be observed on a few specimens. There is a single specimen of a thin scraper flaked in the Levalloisian technique, with the flake scars converging centrally toward an end of the core, a method that has not been found heretofore.

One unfinished (alleged) adze was recovered from the eastern part of cave 1 which was said to be "remarkable" for its offset: that is, the body is crooked so that the cutting edge, splayed on one side, is not at right angles to the axis, to facilitate cutting or chopping while the user is standing up (Fig. 12). There were also found pitted pebbles, probably unfinished ringstones given the nature of the perforations, as well as complete and broken ringstones. The perforations are of "hour glass" shape with flared ends. A large percentage of the pebbles seemed to have served as anvils and hammerstones, while others as the material for the tool itself. A few long pebbles may have been polishers. A collection of small round pebbles were found that may have functioned as sling balls. Also excavated were stones with flat grinding surfaces probably used as whetstones for numerous materials, including the red ocher for the paintings and other tools.

The predominant material used for the tools is limestone (about 34 percent of tools found in cave $1 \mathrm{~A}$ ) although a wide variety of rocks are found, including sandstone (26 percent), quartzite (13 percent), siltstone ( 7 percent), basic igneous rocks ( 8 percent), microgranite $(5$ percent), and granite $(1.4$ percent). There is a small percentage of milky quartz, calcite, and intermediate igneous rocks. One specimen each of agate and fossil wood was also found; the latter unworked. As evidence of both flaking and chipping and grinding and polishing is found, it appears that the distinction between Palaeolithic and Neolithic (at least in Burma) is not all that clear, bearing signs of both, so that continuity is more reasonable to conclude than sudden change introduced from elsewhere.

The presence of a large number of pebbles, flakes, chopper-chopping tools and scrapers, partly ground tools, an incompletely made adze, ringstones and pebbles in different stages of production demonstrates that this particular section of the cave was being used as a tool-making workshop. But the inner sections where the paintings were located, seemed to have been reserved for recreational or the more "spiritual" aspects of the inhabitants' lives.

The soil siftings contained hundreds of bone fragments and molar and canine teeth of mammals, a large quantity of charcoal pieces, shells of land mollusks, a skull of what may have been a deer, tortoise shell fragments, a few pieces of cordimpressed potsherds, and as stated above, pieces of soft hematite (red ocher) one 

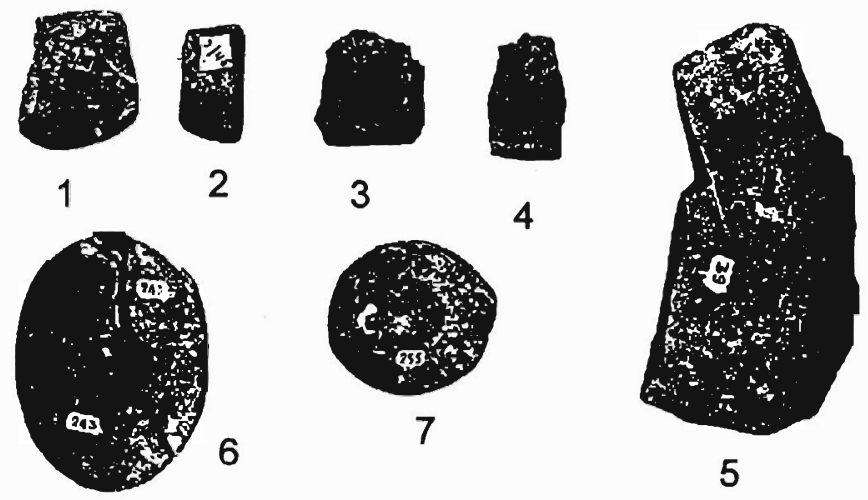

5

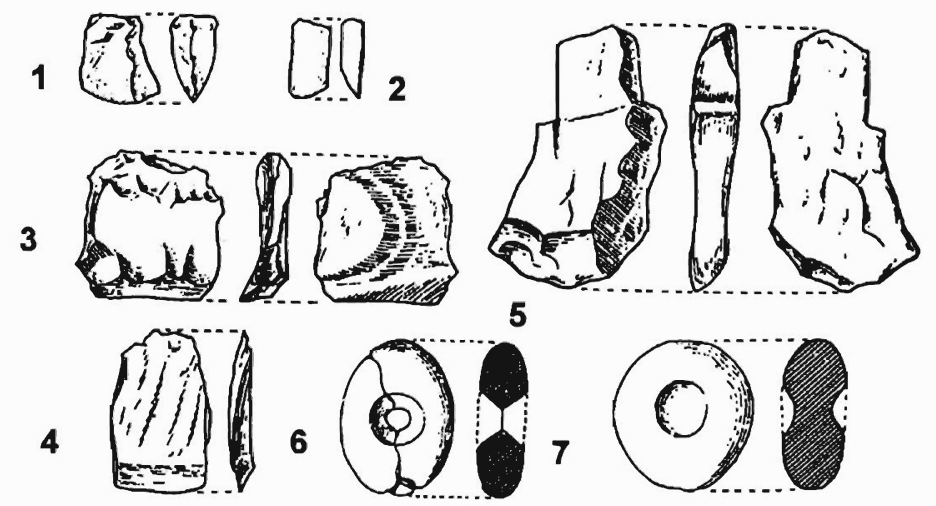

Fig. 12. Edge-ground tools and pitted and perforated pebbles from the Padah-lin caves. 1: quartzite scraper or tiny celt, almost completely polished with sharp convex working edge; 2 : cylindrical pebble scraper, slightly polished body; 3: edge-ground quadrangular scraper, made of dark green quartzitic sandstone; 4: edge-ground rectangular siltstone scraper; 5: shouldered limestone adze with prominent tang; 6: oval pebble with hourglass perforation; 7: oval siltstone pebble, centrally pitted on both sides. (Adapted from Aung Thaw 1971.)

surface of which was smoothly ground as if to produce powder for the pigment used in some of the paintings.

The Padah-lin caves excavations were the first in the study of the "PostAnyathian" culture of Burma that produced scientific radiocarbon and bone collagen dates. Equally important, the data that were the basis for these tests had been recovered by methods which were considered viable (Aung Thaw 1971). These caves produced evidence of charcoal dating to $7740 \pm 125$ B.P. (1950), and bone collagen to $13,400 \pm 200$ B.P. (Aung Thaw 1971:133). Thus, even though the habitation of this cave may span a long period of time, the important dates are the oldest.

But what we currently have does not allow us to know for certain whether the Padah-lin cave dwellers practiced cultivation of plants and domestication of animals to any degree, if at all. Aung Thaw suggests that potsherds and ringstones may indicate some activity related to food production, although as shown above, 
Movius thinks that the ringstones were used as slitting, grinding, and polishing disks, fitted on a spinning wooden lathelike machine used for these tasks. The most we can say is that the tools seem to be linked to other Late Hoabinhian cultures of Southeast Asia.

Since the Padah-lin excavations of the 1960s, several more caves have been discovered and partially excavated, mainly in the Shan, Kayah, Kayin, and Mon states. In April of 2000, in a cave at the foot of Weiponla Stone Hill in Kayin State, an archaeological team including geologists and bone specialists found bones, teeth, and jaws belonging to animals including barking deer, deer, sambar, gaur and wild pigs, turtles, fish, and mussels. No human remains were found. The team also found red ocher used for cave drawings, as well as stone implements thought to be consistent with tools used during the Upper Palaeolithic, along with pieces of charcoal. The cave is made of Maulamyaing (Moulmein) limestone; its entrance is about $50 \mathrm{ft}$ wide with a roof of $35 \mathrm{ft}$ maximum and it was thought to have been inhabited by humans between 9,000 and 6,000 years ago (Myanmar Times 2000).

\section{The Evidence for Metals in Burma}

Copper and Bronze Finds - Opinion differs as to whether there is enough evidence at present to claim a distinct Chalcolithic (Copper) or Bronze Age, per se, for Burma, although copper and bronze artifacts have been found at certain sites. As early as 1938, T. O. Morris wrote that 14 copper or bronze objects are known to have been found within Burma, most of them from the Shan states. In design, they are "very similar to the iron tools of indigenous manufacture used by the present inhabitants of the country" while the copper and bronze axes of Burma were "essentially copies of their Neolithic predecessors," thus suggesting some sort of local, cultural continuity (Morris 1935:9; Fig. 13).

One of the major problems with bronze or other metal objects in Burma is that they were considered thunderbolts (mojo) of Indra (Thagya in Burma) and were therefore prized for their magical and other supernatural qualities, so few found their way to the archaeological department while many were melted down to make plates, on which were inscribed the names of donors, who then deposited them in relic chambers of temples or placed them in different parts of the building under construction. Indeed, over 5,000 of these copper plates were uncovered when an earthquake exposed them in the Shwedagon Pagoda in Yangon (Kyan and $\mathrm{Yi}$ Yi 1995). In addition, no organized research on the size and scale of the Movius expedition had been conducted specifically for metal, not to mention the relative rapidity with which copper, bronze, and iron objects oxidize when exposed to weathering conditions.

Of the 14 copper or bronze artifacts recorded by Morris, 7 are (or were) in the British Museum; 2 in the Pitt Rivers Museum, Oxford; 1 in the Museum of Far Eastern Antiquities, Stockholm; 2 in the collection of a Mr. A. A. Cameron of Kalaw; and 2 fragments in the possession of villagers in Thayetmyo and Lower Chindwin districts. To this inventory, Morris added a socketed bronze celt from Yunnan collected in the 1868 expedition, then placed in the Indian Museum, Calcutta (Morris 1938:95-99).

Eleven of these fifteen objects (including the Yunnan find) are socketed celts. 


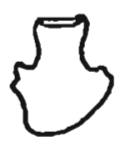

1

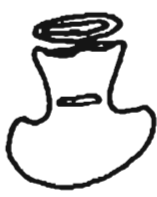

7

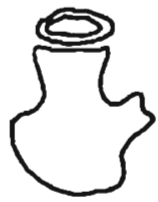

2

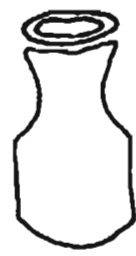

8

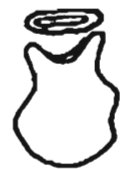

3

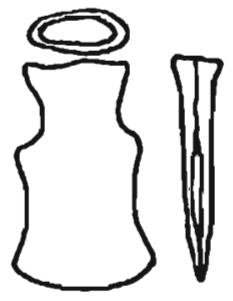

9
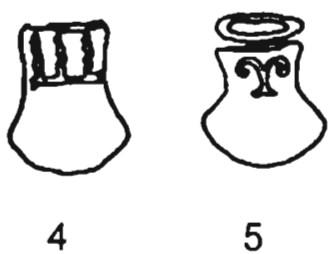

5

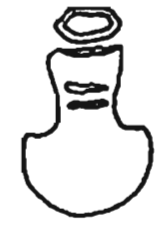

6

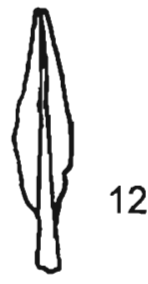

14

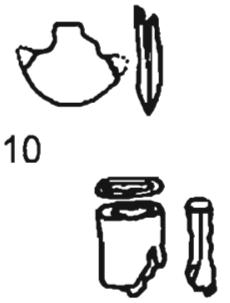

11

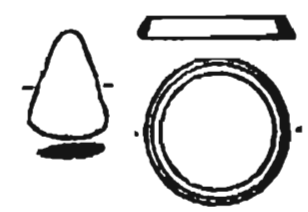

Fig. 13. Copper and bronze tools. 1: Yunnan; 2-3, 5, 9, 14: northern Shan States; 4, 12: southern Shan States; 6, 10: Thayetmyo district; 7-8, 13: trans-Salween Shan States; 11: lower Chindwin district. 1, 9-11: socketed celts; 12: socketed spearhead; 13: flat solid blade; 14: bracelet. All are copper with 2.77 percent tin, a trace of lead, no iron, and no nickel. (Adapted from Nyi Nyi 1988.)

Morris feels that these and the spearhead are of similar design to those found in the late Bronze Age and early Iron Age cultures of portions of Europe and Asia. $\mathrm{He}$ also believes that the Burma copper and bronze objects show little or no sign of Indian influence; rather, like their stone implements, the affinities are primarily with mainland Southeast Asia and China. As no scientific testing of these finds were made we have no idea of their age.

The decision to move the focus from the many stone implements to the much scarcer metal implements did not occur in any organized manner until the 1990s. Several installments appeared in the (then) national newspaper, The Working People's Daily, regarding bronze artifacts found in Burma by Aung Thaw (Aung Thaw 1990). In one of these, he wrote that "artifacts which can be definitely assigned to a copper or bronze age are extremely rare and not a single site pertaining exclusively to an early metal-working culture has yet been discovered" (Aung Thaw 1990:9). By then, approximately 10 new bronze objects had been added to Morris' collection of 14 implements. Seven of the new ones are socketed celts, and 3 are spearheads. (The spearheads also show stylistic affinity with those found at Ban Chiang [White 1982:77, 91].) All are surface finds from Upper Burma, most in the dry zone between Kawlin in the north to Thayetmyo in the south.

More specifically, a socketed celt with rounded edges was found at each of the following places: Chingon in Kawlin Township; Butaung Village in Yaw 
Township; Myinhmwe Village in Sagaing Township; Thaphanchaung Village in Pyawbwe Township, near a major "Pyu" city (Binnaka); and Thayetmyo Township. The bronze celts and spearhead came from Taunggaing Village in Myitnge Township. One spearhead weighing $181.06 \mathrm{~g}$ was recovered at Thitsongale Village in Yamethin Township. The weights of the socketed celts range from 97.502 $\mathrm{g}$ to $142.852 \mathrm{~g}$ with one large one weighing $181.06 \mathrm{~g}$. None, as of this writing, has been tested to determine its age.

Then in 1998, a cemetery was excavated at Nyaung-gan Village in Budalin Township near Monywa, which produced a rich collection of burial goods including many bronze and stone implements, a site Moore and Pauk Pauk's paper in this volume discusses.

Iron at Taungthaman - Iron was also well known to the urbanized period in Burma, currently assigned to the so-called Pyu people. They also worked in fine metals and in bronze. They cremated their dead and buried the remains in earthenware urns. Large stone urns, and perhaps also bronze ones were used for the remains of royalty. Two such bronze urns were discovered at Sri Ksetra; one during the excavations of 1927-28, and the other in 1969-70 at a burial mound together with several earthen urns. In the field season of $1966-67$, an ornately molded bronze bell was discovered, at the same mound where the famous five dancing figures in bronze were discovered, now displayed at the National Museum.

The earliest dated site for the urbanized period of Burma is apparently Taungthaman, just outside the city of Amarapura, one of Burma's capitals built in the eighteenth century, located in the dry zone (Map 1). According to Janice Stargardt, Thaungthaman represents the "very last and most sophisticated stage of stone technology co-existing with the beginnings of an initially crude, iron-working metallurgy," around 500 B.C. (Stargardt 1990:13-14). The site is located about 3 $m$ above the Irrawaddy floodplain. Natural erosion revealed burials in the late 1960 s and excavations began in the early 1970s under the direction of Aung Thaw and Sein Maung Oo, Archaeological Survey of Burma.

Thermoluminescence dates on specimens of pottery and iron found in the graves show the earliest to be 2660 B.P. (i.e., before 1950) \pm 200 , and the latest to be 2360 B.P. \pm 235 . That is 710 B.C. \pm 200 and 410 B.C. \pm 235 , respectively. The iron specimen was a fish hook found on the chest of a skeleton, perhaps a fisherman during his life. The latest date does not mean the site was abandoned, as virtually every prehistoric site continued to be inhabited during historic times; indeed many are still today.

The iron items recovered from the burial sites at Taungthaman include the above-mentioned fish hook, knife blades, short swords, and several iron lumps that may have been used as money, since lead was used as money subsequently at Pagan, or were simply unworked raw material. The metallurgical analysis obtained by Stargardt reveals that iron was melted (between 1,000 and $1,500^{\circ} \mathrm{C}$ ) but the stage where the highest temperatures would have burned out impurities (approximately $1,500^{\circ} \mathrm{C}$ ) had not been reached. These specimens, then, suggest that Taungthaman was still at an early stage of iron working (Stargardt 1990:28). We know that Beikthano Myo, which is later than Taungthaman, is carbon dated (conservatively) to the second century B.C. where iron working was well estab- 
lished, with discoveries of nails, sockets, plates, spikes, and similar construction hardware (Aung Thaw 1968).

It is difficult to reach any firm conclusions on the iron site data at present, particularly in the absence of scientific testing for all of it, not least because late stone culture persisted until the beginning of the Christian era when iron working was already known in some parts of the country.

Thus, by 180 B.c. (earlier if Taungthaman is included) Burma was already in an urban age, influenced, if not dominated by the Tibeto-Burman-speaking people that we have come to call the Pyu, practicing Buddhism, and building religious edifices. I have labeled this "the formative age" in Burma's history elsewhere (Aung-Thwin 1982-1983) the precursor of the first unified kingdom of Burma: Pagan and the "Classical Age," beyond the scope of this particular paper.

\section{RECENT ACTIVITIES IN PREHISTORY}

The new National Museum in Rangoon built in the mid-1990s now houses some of the best prehistoric evidence to date (occupying an entire wing of a floor) while regional and site museums (at Mrauk-U in Arakan and Pagan) also contain important data. In February of 1997, a geological expedition unearthed several important primate fossils which led to other expeditions in March and April that also produced additional data. Such finds reportedly brought palaeontologists from the United States, France, Morocco, Thailand, and Japan. In 1998 and 1999, several conferences were held on prehistory and early history to which more foreign experts were invited, contributing importantly to the field, both in terms of discussion at the conference and in subsequent publications of the proceedings (Kyi Kyi Hla 1998). And although there is excitement among Burma scholars, most individuals knowledgeable in the field advise caution against making any sweeping conclusions until more reliable evidence is in.

With the national archives now (2000) opened to the international and domestic public for holdings up to 1948 , one suspects and hopes that this same kind of policy will prevail with regard to holdings of prehistoric data in the department of archaeology that are not already available in the national and regional museums open to the public. Hence, the creation of and access to a web site on primate finds of Burma during the last decade itself suggests a new and more open policy regarding research in such fields. Indeed, many valuable assessments and significant contributions can be made simply from existing, public data, if only those properly trained in the field were willing and able to do so.

The fact of the matter is, however, the last graduate student from Burma trained in archaeology in the United States is $U$ Nyunt Han, now head of archaeology in Burma and near retirement. He received his Masters from the University of Pennsylvania under the late Chester Gorman in the 1960 s. And the last archaeologist from Burma trained outside the country elsewhere was the late $U$ Aung Thaw, who obtained his training in New Delhi. Currently, there is only one graduate student being trained in the United States in Burma's archaeology (who is not from Burma but Singapore) whose focus is on the Pyu, and he is enrolled at the University of Hawai'i. The University of Sydney has one graduate student (Bob Hudson, in this volume) focusing on the pre-Pagan era. The University of Singapore, Faculty of Arts and Sciences, has also made a major contri- 
bution to the field of Burma's prehistory by providing a graduate level fellowship to a Burmese student to obtain his Ph.D. in archaeology (there is no one with such a degree in Burma presently) who is expected to eventually return to Burma and contribute to the field. There may be others in Japan and Europe, but as it was nearly forty years ago, one can still count all of them on one hand.

Thus, the major problem in Burma's prehistory as a field of study remains the scarcity of properly trained personnel knowledgeable about the latest issues, problems, and methods, and of course, the costs of such training. Once trained, more costs must be anticipated as scientific testing of excavated data incurs even more expenses if it is to meet the standards required by the prehistorians of today.

\section{NOTES}

1. The entire run of the JBRS is now conveniently available on CD-ROM from Myanmar Book Promotion and Service Co., Ltd. (Thailand).

2. Thus, "Pagan dust" has nothing to do with the alleged climatic changes due to the deforestation and firing of wood to make the millions of bricks for the thousands of temples in the eleventh to thirteenth centuries A.D. as MacKenzie theorized (MacKenzie 1913:40-46).

3. This is, however, disputed (Ba Maw et al. 1999).

4. One could, I suppose, compare Burma's lack of progress in archaeology to that of other Southeast Asian countries, but the situations in each after independence could hardly have been more different. For fifty years, until recently, the central government in Burma has had to fight a civil war on dozens of fronts, nearly losing the capital during the first few months after independence. to rebel advances. The devastation of World War II itself is comparable only to Germany's: no other Southeast Asian nation suffered comparable infrastructural damage. It is true that Viet Nam also had a prolonged war, but whereas because it received massive Soviet and Chinese aid for its war effort, it could channel its own resources to archaeology. Thailand had the luxury of never having to go through a civil war, while Malaysia's "Emergency" was short-lived and involved basically one group, the communists. Neither Indonesia nor the Philippines had to go through a prolonged civil war. Cambodia's problems were of a devastating kind as well, and its lack of progress in archaeology shows. It has nothing to do with the vision of its leaders: it had to do with survival.

\section{REFERENCES CITED}

AUNG THAW

1968 Excavations at Beikthano. Rangoon: Ministry of Union Culture.

1971 The Neolithic culture of the Padah-lin caves. Asian Perspectives 14:123-133.

1972 Historical Sites in Burma. Rangoon: Ministry of Union Culture.

1990 "Bronze culture and tradition in Myanmar." The Working People's Daily' (Sunday, 2 September): 9.

Aung-Thwin, Michael

1982- Burma before Pagan: The status of archaeology today. Asian Perspectives 25:1-21.

1991 The spiral in early Burmese and Southeast Asian history. Journal of Interdisciplinary History 21(4):572-602.

Ba Maw, Than Tun Aung, Pe Nyein, and Tin Nyein

1999 Artifacts of Anyathian Cultures found in a single site, in Essays Given to Than Tun on His 75 th Birthday: Studies in Myanma History: 7-15, vol. 1. Yangon: Innwa Publishing House.

Brown, J. C.

1917 Catalogue of Prehistoric Antiquities in the Indian Museum at Calcutta. Simla: Government Central Press.

1931 Relics of the stone age in Burma. Journal of the Burma Research Society $21: 33-43$.

Chang, K. C.

1986 The Archaeology of Ancient China. New Haven: Yale University Press. 
CHHiBber, H. L.

1934 The Geology of Burma. London: Macmillan.

ClegG, E.L.C.

1938 The geology of the Minbu and Thayetmyo districts, Burma. Memoirs of the Geological Survey of India $72: 137-317$.

CotTer, G. DE P.

1918 The geotectonics of the Irrawaddy Basin. Journal of the Royal Asiatic Society of Bengal $14: 409-420$.

Das Gupta, H. C.

1923 Indian prehistory. Journal of the Department of Science 5:10-15.

DE Terra, Helmut

1944 Component geographic factors of the natural regions of Burma. Annual Association of American Geographers 34:67-96.

de Terra, Helmut, and H. L. Movius, Jr.

1943 Research on early man in Burma. I - The Pleistocene of Burma by H. de Terra. II-The Stone Age of Burma by H. L. Movius, Jr. Transactions of the American Philosophical Society $32: 271-393$.

Eiji NitTa

1987 The situation of the Neolithic culture of Padah-lin caves in the context of Southeast Asian Prehistory, in Burma and Japan: Basic Studies on Their Cultural [sic] and Social Structure: 161-168. Tokyo: The Burma Research Group.

Evans, P., AND C. A. SANSON

1941 The geology of British oilfields. Part 3-The oilfields of Burma. Geological Magazine $78: 321-350$.

Grimes, G. E.

1900 Geology of parts of the Myingyan, Magwe, and Pakokku districts, Burma. Memoirs of the Geological Survey of India 28:30-71.

KYAN, DAW, AND YI YI DR

1995 Myanmar Thamaing Thutethana Sasaung [Myanmar Historical Research Journal]. 1:195211. Yangon: Universities Historical Research Centre.

KYI KYI HLA

1998 The Pondaung Fossil Seminar. Myanmar Perspectives 3(2):21-27.

MacKenzie, J. C.

1913 Climate in Burmese history. Journal of the Burma Research Society 3(1):40-46.

Mitra, P.

1927 Prehistoric India. Calcutta: University of Calcutta.

MORRIS, T. O.

1932 A palaeolith from Upper Burma. Journal of the Burma Research Society 22:19-20.

1935 The prehistoric stone implements of Burma. Journal of the Burma Research Society $25: 1-$ 39.

1936a A palaeolith from Yenangyaung. Journal of the Burma Research Society 26:119-121.

$1936 b$ The Konbyin Terrace of the Irrawaddy at Thayetmyo. Journal of the Burma Research Society 26: 163-169.

1937 Prehistoric stone implements from the Konbyinmyint of the Irrawaddy and Paunglaung rivers. Journal of the Burma Research Society 27:74.

1938 Copper and bronze antiquities from Burma. Journal of the Burma Research Society 28(2): 95-99.

Movius, H. L. JR.

1948 Palaeolithic cultures of the Far East. Transactions of the American Philosophical Society 38(4) : 335-411.

Myanmar Times

2000 "Discovery of Stone Age tools evidence cave men lived here." Myanmar Times, August 713, p. 6.

Noetring, Fritz

1894 On the occurrence of chipped (?) flints in the Upper Miocene of Burma. Record of the Geological Survey of India 27:101-103. 
1895 The development and sub-division of the Tertiary system in Burma. Records of the Geological Survey of India $28: 59-86$.

1897 On the discovery of chipped flint flakes in the Pliocene of Burma. Natural Science $10: 233-241$.

NYI NYI

1988 Old Stone Age of Burma. Working Peoples Daily.

Oldham, R. D.

1895 The alleged Miocene man in Burma. Natural Science 7:201.

PASCOE, E. H.

1912 The oilfields of Burma. Memoirs of the Geological Survey of India 40(1):53-54.

SMITH, R. A.

1920 Guide to the Antiquities of the Bronze Age. London: British Museum.

1926 Guide to the Antiquities of the Stone Age. London: British Museum.

STAMP, D. L.

1922 An outline of the Tertiary geology of Burma. Geology Magazine 59:481-501.

STARGARDT, JANICE

1990 The Ancient Pyu of Burma, vol. 1. Cambridge and Singapore: PACSEA and ISEAS.

Swinhoe, R.J.C.

1903 Some further notes on chipped flints at Yenangyaung, Upper Burma. Zoologist 7:254259.

THAN TUN

1996 Prehistoric researches in Myanmar, in Traditions in Current Perspective: Proceedings of the Conference on Myanmar and Southeast Asian Studies, 15-17 November 1995, Yangon: 25-29. Yangon: Universities. Historical Research Centre.

TheobaLd, W.

1873 The geology of Pegu. Memoirs of the Geological Survey of India 10:167-171.

White, Joyce C.

1982 The Discovery of a Lost Bronze Age: Ban Chiang. Philadelphia: The University of Pennsylvania Press.

\section{GENERAL BIBLIOGRAPHY}

Aung Myint

1998 Ancient Royal Cities of Myanma from Aerial Photographs. Yangon: Ministry of Culture.

Aung Thwin, Michael

1994 Principles and Patterns of the Precolonial Burmese State, in Tradition and Modernity in Myanntar: Proceedings of an International Conference Held in Berlin from May $7^{\text {th }}$ to May $9^{\text {th }}$, 1993:15-44. Ed. U. Gartner and J. Lorenz. Berlin: Humboldt-Universitat Fakultatsinstitut fur Asien- und Afrikawissenschaften.

BA MaW

1995 Research on the early man in Myanmar. Myanmar Historical Rescarch Journal 1 (November) : 213-220.

Burкiтt, M. C.

1943 Research on early man in Burma. Nature 152:335.

Ciochon, Russell L.

1985 Fossil ancestors of Burma. Natural History 10:26-36.

Colbert, E. H.

1938 Fossil mammals from Burma in the American Museum of Natural History. Bulletin of the American Museum of Natural History $74: 255-436$.

1943 Pleistocene vertebrates collected in Burma by the American Southeast Asian Expedition. Transactions of the American Philosophical Society 32:395-429.

Cole, G.A.J.

1895 Miocene Man in Burma. Natural Science 7:295. 
JONES, T. R.

1894 Miocene man in Burma. Natural Science 5:345-349.

Nay Thaung Thaung, Bo San, Hla Myint(1), Ther [T]un, Min Aung, Hla Myint(2), and BA MAW

1999 The First Find of Pliopithecus in Myanmar, in Essays Given to Than Tun on his $75^{\text {th }}$ Birthday: Studies in Myanmar History, 1:1-6. Yangon: Innwa Publishing.

SWINHOE, R.J.C.

1902 Prehistoric Man in Burma. Zoologist: 321-336.

Teilhard de Chardin, P.

1933 Sinanthropus Cultural Remains. Memoirs of the Geological Survey of China. Series A, no. $11: 110-141$.

\section{ABSTRACT}

The circumstances under which the study of prehistory evolved in Burma are summarized and some of the issues, problems, and research topics are identified for future students of Burma's prehistory. Keywords: Anyathian, Hoabinhian, Pleistocene terraces, Upper Burma, Padah-lin caves, Taungthaman, Beikthano Myo, Chauk, Kyaukpadaung, Irrawaddy, Chindwin, Pagan, Nyaung-U, Magwe, Minbu, Pakokku, New Gwe Hill, Chelleo-Acheulean, copper, bronze, Halin, Nyaunggan, Budalin Township, Monywa. 